\title{
THE EFFECT OF INTELLECTUAL INTELLIGENCE, EMOTIONAL INTELLIGENCE, SPIRITUAL INTELLIGENCE AND TYPES OF ACCOUNTANT PROFESSIONS AT ETHICAL ATTITUDES OF MASTER ACCOUNTING STUDENTS
}

\author{
Jatmika Luh Asri*, Sukartha I Made \\ Master Program of Accounting, Faculty of Economics and Business, \\ University of Udayana, Indonesia \\ ${ }^{*}$ E-mail: asriloeh@gmail.com
}

\begin{abstract}
The purpose of this study to provide empirical evidence about the influence of intellectual intelligence, emotional intelligence, spiritual intelligence, and the type of accounting profession on the ethical attitude of master accounting student. Sampling using sample saturated with total sample counted 130 responders. Hypothesis testing tool used is multiple linear regression analysis. The result of research proves that intellectual intelligence and emotional intelligence have an effect on the ethical attitude of accounting master student, which means that the higher intellectual intelligence and emotional intelligence of the students, the better the ethical attitude of the students. The results of this study also shows the spiritual intelligence and accountant profession type does not affect the ethical attitude of master accounting student, this is due to the many factors outside the spiritual intelligence and the type of accounting profession that influence ethical attitudes and able to exclude the influence of spiritual intelligence and accounting profession types of ethical attitude of accounting master student.
\end{abstract}

\section{KEY WORDS}

Intellectual intelligence, emotional intelligence, spiritual intelligence, accountant profession type, ethical attitude.

Ethical attitude is the basic thing that already exists in human, because of the basic environment of every human family interact and form a basic attitude in accordance with the environment. The human developmental gap from child to adult goes through a long phase and one of is the formation of attitudes.

Master accounting students get education norms and ethics contained in the environment lectures. These ethical values will influence him in making a decision to do something good or bad, and create a good standard of self in society. Student of master accounting degree as an accountant has ethical attitudes gained during college and work experience.

Development of ethical attitudes on master accounting students through education that sharpens intellectual intelligence, emotional intelligence, and spiritual intelligence so that learners are not only smart in the science of accounting but also in behaving. Intellectual intelligence, emotional intelligence, spiritual intelligence relate to the theory of planned behavior which says that humans tend to act with the intention and perception of control through certain behaviors. The intention is influenced by attitude, subjective norm, and behavior control. Application of a balanced curriculum between intellectual intelligence, emotional intelligence, spiritual intelligence is expected to occur a positive change for the enforcement of professional ethics of accountants in Indonesia. (Nasirwan, 2011).

Intellectual intelligence is the ability to adapt to new needs, using the tools of thought that are appropriate to the purpose (Purwanto, 2003). Based on research by (Jamaluddin \& Indriasari, 2011), (Lucyanda, 2013) and (Wardana \& Mimba, 2016) the more intelligence someone, it will encourages them to behave ethically

Emotional intelligence as the ability to sense, understand and effectively apply emotional power and sensitivity as a source of human energy, information, connections and influence (Ayman, Sawaf, and Cooper Robert, 1998). Based on a study by (Shahhosseini, 
Daud Silong, \& Nak Uli, 2012), (Ika, 2011), (Dewanto \& Nurhayati, 2009)) high levels of emotional intelligence have a positive impact to manage their own emotions.

(Pasiak, 2002) states that spiritual intelligence transcends the present and human experience, and is the innermost and most important part of human. Based on research by (Wardana \& Mimba, 2016), (Trihandini, 2005), (Chakraborty \& Chakraborty, 2004) spiritual intelligence encourages a person to be ethical because of the calm and confidence in dealing with the problem certain attitude and behavior will be controlled.

The employment background of the master accounting student contributes to the process of developing ethical attitudes that are pointed out in their daily lives. The work experience in accounting masters as an accountant is based on accountant ethics in the form of accountant code of ethics. Accountant profession except the public accountant has not yet formulated its code of ethics but based on IFAC's fundamental ethical principles an accountant must have integrity, objectivity, professional competence, and caution, confidentiality, professional behavior (Fitri \& Utami, 2006).

The International Federation of Accountants defines the accounting profession as all occupational fields employing accounting skills, including the work of public accountants, management accountants working in industrial, financial or trade firms, accountants working in government, and accountants as educators.

Master accounting student make ethics an important part of their curriculum. They must adhere to the ethics and codes of conduct applicable to the world of accounting. This research is done to master accounting student because they are accountants who have worked in various profession accountant. Master accounting students who already have knowledge in accounting and also ethics at bachelor degree are expected to apply it well in the business world. The same fundamental principles of ethics and educational background are one of the factors influencing the ethical attitude of the accounting master student.

\section{LITERATURE REVIEW}

Theory of planned behavior. Ajzen developed a theory which is a refinement of the reason action theory proposed by Ajzen and Fishbein, in 1975. Discussion of the theory of planned behavior is the same as the theory of reason action which is the intention of individuals to perform certain behaviors. Intense can see the motivation factors that affect behavior. Reason action theory says there are two determinants of intention: personal attitudes and subjective norms.

The attitude was originally defined as a condition for the emergence of an action. The concept then develops more broadly and illustrates a tendency to consistently respond favorably or unpleasantly to an object, this tendency being the result of learning, not innate or offspring. Factors that influence the formation of attitudes include internal factors including gender, age, education, emotional, and external factors that include mass media, educational institutions, religious institutions, jobs and society (Azwar, 2005)

The attitude structure is divided into three mutually supporting components according to (Secord \& Backman, 1964) that is cognitive component is a component of knowledge which will form certain belief and opinion about attitude object, affective component is component that related with feeling of pleasure or displeasure, it can be said related to individual emotional states so that it is evaluative. This component is closely related to the value system adopted by the attitude, and the conative component is a component of attitude in the form of a person's readiness to behave related to the attitude object.

Ethics. Ethics derived from the Greek is "Ethos", which means the character of morality or custom. Ethics is usually closely related to the moral word which is a Latin term, "Mos" and in its plural form "Mores", which also means a custom or a person's way of life by doing good deeds (morality) and avoiding action the bad. (Ward, Ward, \& Deck, 1993) state that ethics includes a complex determination process of what a person needs to do in a particular situation characterized by the combination of the experience and learning of each individual.

Ethics as a moral teaching is generally not written. But for a professional organization (eg accountants, doctors, lawyers), ethical attitudes are set forth in written rules called codes 
of ethics. The code of ethics is designed to serve as a rule of ethical conduct for members of the profession aimed at maintaining the reputation and trust of the community so that the profession can still exist and survive.

The accounting profession has the responsibility to act in the public interest. This Code of Professional Accountants is an adoption of the Handbook of the Code of Ethics for Professional Accountants 2016 Edition issued by the International Ethics Standards Board for Accountants of the International Federation of Accountants (IESBA-IFAC). In the process of drafting, IAI (Indonesian Institute of Accountants) coordinates with the Indonesian Institute of Certified Public Accountants (IAPI) and the Indonesian Institute of Management Accountants (IAMI) in accordance with the Memorandum of Understanding between IAI, IAPI and IAMI on the cooperation of professional development of accountants in Indonesia. Ethical Principles in the IAI Code of Ethics consist of five, namely Integrity, Objectivity, Competence and Prudence Professional Confidentiality, Professional Behavior.

Intellectual intelligence. (Zakiah, 2013) mentions intellectual intelligence is a person's ability to acquire knowledge, master and apply it in the face of problems experienced by students. The intellectual intelligence possessed by each individual can be the basis of control in behaving. Intellectual intelligence still affects the mindset of a student, because intellectual intelligence is the first intelligence developed that can make a student think rationally to learn to account and understand it. Aspects of Intellectual Intelligence include problem-solving skills, verbal intelligence, practical intelligence.

Emotional intelligence. (Goleman, 2000) defines emotional intelligence as the ability to recognize the feelings of oneself and the feelings of others, motivate oneself, and manage emotions well on oneself and in relationships with others. Emotional intelligence requires a person to learn to recognize, appreciate the feelings of self and others and respond appropriately and effectively apply emotional energy in everyday life. Emotional intelligence to benchmark the ability of individual emotional control in influencing attitudes and behavior (Jogiyanto, 2007). Aspects of emotional intelligence include self-awareness, self-regulation, motivation, empathy, social skills.

Spiritual intelligence. Spiritual intelligence is more related to the enlightenment of the soul. People who have high spiritual intelligence is able to make sense of life by giving a positive meaning to every event, problem, even the suffering that happened. By giving a positive meaning will be able to raise the soul and do positive actions and actions. Sufficient spiritual intelligence is a contributing factor in the control of individual behaviors in accordance with objective attitudes and norms prevailing in the environment. Individuals with good spiritual intelligence have more controlled attitudes and behaviors than those with poor spiritual intelligence. Aspects of spiritual intelligence include the ability to be flexible, high self-awareness, ability to deal with and utilize suffering, ability to deal with and overcome pain, reluctance to cause unnecessary loss, quality of life, holistic views, tendency to ask questions. ability to position oneself.

Types of accountant professions. The international federation of accountants defines the accounting profession as all occupational fields employing accounting expertise, including the field of public accountant work, management accountants working in industrial, financial or trade firms, accountants working in government, and accountants as an educator.

\section{METHODS OF RESEARCH}

The population of this research is the students of Master Accounting Program which amounts to 140 students. In this study used the total sampling method. Sources of data using the primary data in this study obtained from qualitative data from the distribution of questionnaires to the master accounting students as respondent. Independent variables in this study are intellectual intelligence, emotional intelligence, spiritual intelligence and different types of the accounting profession. The dependent variable in this study is the ethical attitude of master accounting students. The determination of the value of the different types of accounting profession (JP) is $N=5$, the category that can be used is $5-1=4$ (Sugiarto, 2000). 
Description of the determination of JP value as follows:

- $\quad J P 1=1$ if the profession is a public accountant, if not 0 ;

- $\quad \mathrm{JP} 2=1$ if the profession is a management accountant, if not 0 ;

- $\quad \mathrm{JP3}=1$ if profession as educator accountant, if not 0 ;

- $\quad \mathrm{JP4}=1$ if the profession is a government accountant, if not 0 .

The data collection in this study used questionnaires adopted from the Ethical Ethics Principles of IAI, (Robins \& Judge, 2008), (Goleman, 2009) and (Zohar, D. dan Marshall, 2005) using 5 rating scale.

Data analysis on data that has been collected includes descriptive statistics, classical assumption test, and multiple regression analysis. Regression model in this research is expressed as follows:

$$
\mathrm{SE}=\alpha+\beta 1 \mathrm{KI}+\beta 2 \mathrm{KE}+\beta 3 \mathrm{KS}+\beta 4 \mathrm{JP}_{1}+\beta 4 \mathrm{JP}_{2}+\beta 4 \mathrm{JP}_{3}+\beta 4 \mathrm{JP}_{4}+\mathrm{e}
$$

Where:

SE: Ethical Attitude;

a: Constants;

ß: Regression Coefficient;

$\mathrm{KI}$ : Intellectual Intelligence;

KE: Emotional Intelligence;

KS: Spiritual Intelligence;

$\mathrm{JP}_{1}$ : Public Accounting Profession;

$\mathrm{JP}_{2}$ : Professional Management Accountant;

$\mathrm{JP}_{3}$ : Professional Accountant Educator;

$\mathrm{JP}_{4}$ : Government Accounting Profession;

e: error term.

The hypothesis in this research formulated as follows:

- $\mathrm{H} 1$ : Intellectual intelligence positively affects the ethical attitude of master accounting students;

- H2: Emotional intelligence positively affects the ethical attitude of master accounting students;

- H3: Spiritual intelligence positively affects the ethical attitude of master accounting students;

- H4: Different types of accounting professions have a positive effect on the ethical attitude of master accounting students.

\section{RESULTS OF STUDY}

Based on the result of instrument test, consisting of validity and reliability test, it is obtained that all statements have coefficient more than 0.3 so that all instruments are valid. For the reliability test, all research instruments are declared reliable because each statement item has a reliability coefficient greater than the value of Cronbach alpha 0.6. This suggests that such measurements can provide consistent results when re-measurement of the same subject matter.

The questionnaires were distributed as many as 140 questionnaires, which were returned as many as 140 questionnaires and were worthy of use as many as 130 questionnaires, due to complete and qualified fill. The results of the calculation of the data obtained shows the return rate of respondents (response rate) of 100 percent and the return rate that can be analyzed (useable response rate) of 93 percent.

Statistic descriptive. Variables of intellectual intelligence $(\mathrm{KI})$ are represented by 10 statements and each statement is measured on a scale of 1-5. Descriptive statistical results in Table 1 shows the value of the assessment of respondent responses to intellectual intelligence (X1) is high, this can be seen from the total average score indicators on 
intellectual intelligence variable of 4.01 . The highest average score for intellectual intelligence variables was 4, 01 on the indicator of practical intelligence ability.

The emotional intelligence variable (X2) is represented by 23 statements and each statement is measured on a scale of 1-5. Rating of respondent emotional intelligence (X2) is high, this can be seen from the total average score indicator on the emotional intelligence variable of 3.90. The highest average score of the emotional intelligence variable was 3.97 on the self-motivating ability indicator.

The spiritual intelligence variable (X3) is represented by 18 statements and each statement is measured on a scale of 1-5. Assessment of respondent answers to spiritual intelligence (X3) is high this can be seen from the total average score indicator on Spiritual Intelligence variable of 3.98. The highest average score of the spiritual intelligence variables is 4.14 on the quality of life indicator.

The student ethical attitude variable $(\mathrm{Y})$ is represented by 29 statements and each statement is measured on a scale of 1-5. Assessment of respondent answers to student ethical attitude $(Y)$ is high this can be seen from the total average score indicator on student ethical attitudes of 4.10 .

Table 1 - Statistic Descriptive

\begin{tabular}{|l|l|c|}
\hline \multicolumn{1}{|c|}{ Variable } & \multicolumn{1}{|c|}{ Indicator } & Score \\
\hline \multirow{4}{*}{ Intellectual Intelligence $(X 1)$} & a. Problem-solving skills & 3,99 \\
\cline { 2 - 3 } & b. The ability of verbal intelligence & 4,00 \\
\cline { 2 - 3 } & c. The ability of practical intelligence & 4,01 \\
\cline { 2 - 3 } & Mean KI (X1) & 4,01 \\
\hline \multirow{5}{*}{ Emotional intelligence (X2) } & a. The ability to recognize oneself & 3,96 \\
\cline { 2 - 3 } & b. Self-control & 3,87 \\
\cline { 2 - 3 } & c. Self-motivating ability & 3,97 \\
\cline { 2 - 3 } & d. Ability to empathize & 3,82 \\
\cline { 2 - 3 } & e. Social skills & 3,89 \\
\cline { 2 - 3 } & Mean KE (X2) & 3,90 \\
\hline \multirow{5}{*}{ Spiritual Intelligence (X3) } & a. Be flexible & 3,88 \\
\cline { 2 - 3 } & b. Self-awareness & 4,08 \\
\cline { 2 - 3 } & c. Facing and exploiting the suffering & 4,06 \\
\cline { 2 - 3 } & d. Faced and overcome the pain & 3,78 \\
\cline { 2 - 3 } & e. Reluctance to cause harm & 3,86 \\
\cline { 2 - 3 } & f. Quality of life & 4,14 \\
\cline { 2 - 3 } & g. A holistic view & 3,95 \\
\cline { 2 - 3 } & h. The tendency to ask questions & 4,01 \\
\cline { 2 - 3 } & i. Ability to position oneself & 3,76 \\
\cline { 2 - 3 } & Mean KS (X3) & 3,98 \\
\hline \multirow{5}{*}{ Student Ethical Attitudes (Y) } & a. Integrity & 4,09 \\
\cline { 2 - 3 } & b. Objectivity & 4,12 \\
\cline { 2 - 3 } & c. Competence and caution & 4,03 \\
\cline { 2 - 3 } & d. Confidentiality & 4,14 \\
\hline & e. Behavior of professionalism & 4,18 \\
\cline { 2 - 3 } & Mean SE (Y) & 4,10 \\
\hline
\end{tabular}

Classic assumption test. Normality test results can be seen in Table 2 which shows the coefficient of Asymp. Sig (2-tailed) of 0.20 is greater than 0.05 . This means that the data in this study is normally distributed.

Table 2 - Normality Test

\begin{tabular}{|c|c|}
\hline $\mathrm{n} / \mathrm{n}$ & Unstandardized Residual \\
\hline $\mathrm{N}$ & 130 \\
\hline Kolmogorov-Smirnov Z & 0,059 \\
\hline Asymp. Sig. (2-tailed) & 0,20 \\
\hline
\end{tabular}


Multicollinearity Test based on Table 3 , it is known that the tolerance value of each variable is greater than $10 \%$ or 0.1 and the VIF value of each variable is also smaller than 10. This indicates that the regression does not occur in multicollinearity symptoms.

Table 3 - Multicollinearity Test

\begin{tabular}{|c|c|c|}
\hline Variable & Tolerance & Variance Inflation Factor (VIF) \\
\hline $\mathrm{Kl}$ & 0,730 & 1,371 \\
\hline $\mathrm{KE}$ & 0,676 & 1,480 \\
\hline $\mathrm{KS}$ & 0,812 & 1,231 \\
\hline $\mathrm{JP}^{1}$ & 0,487 & 2,053 \\
\hline $\mathrm{JP}^{2}$ & 0,562 & 1,779 \\
\hline $\mathrm{JP}^{3}$ & 0,579 & 1,727 \\
\hline $\mathrm{JP}^{4}$ & 0,553 & 1,807 \\
\hline
\end{tabular}

The result of heteroscedasticity test in Table 4 shows that the value of Sig. each independent variable is above 0.05 so it can be concluded that the regression model used does not contain symptoms of heteroscedasticity.

Table 4 - Heteroscedasticity Test

\begin{tabular}{|c|c|c|}
\hline Variable & Sig. & Status \\
\hline $\mathrm{KI}$ & 0,775 & Non heteroscedasticity \\
\hline $\mathrm{KE}$ & 0,797 & Non heteroscedasticity \\
\hline $\mathrm{KS}$ & 0,110 & Non heteroscedasticity \\
\hline $\mathrm{JP}^{1}$ & 0,655 & Non heteroscedasticity \\
\hline $\mathrm{JP}^{2}$ & 0,059 & Non heteroscedasticity \\
\hline $\mathrm{JP}^{3}$ & 0,534 & Non heteroscedasticity \\
\hline $\mathrm{JP}^{4}$ & 0,803 & Non heteroscedasticity \\
\hline
\end{tabular}

Multiple Linear Regression Analysis. Based on Table 5, the result of adjusted R Square of 0.322 means $32.2 \%$ variation in acceptance of ethical attitude of master accounting student can be explained by variation from intellectual intelligence variable, emotional intelligence, spiritual intelligence, and accountant profession type. While the rest of 67.8 percent influenced by other factors not described in the model.

Table 5 - Results of Coefficient of Determination (Adjusted $R^{2}$ )

\begin{tabular}{|c|c|c|c|c|}
\hline Model & $\mathrm{R}$ & $\mathrm{R}$ Square & Adjusted R Square & Std. The error of the Estimate \\
\hline 1 & 0,599 & 0,359 & 0,322 & 1.190 .609 \\
\hline
\end{tabular}

Table 6 - F Test Testing

\begin{tabular}{|c|c|c|c|c|c|c|}
\hline \multicolumn{2}{|c|}{ Model } & Sum of Squares & $\mathrm{df}$ & Mean Square & $\mathrm{F}$ & Sig. \\
\hline \multirow{3}{*}{1} & Regression & 9.686 .134 & 7 & 1.383 .733 & 9.761 & 0,000 \\
\cline { 2 - 7 } & Residual & 17.294 .096 & 122 & 141.755 & & \\
\cline { 2 - 7 } & Total & 26.980 .229 & 129 & & & \\
\hline
\end{tabular}

Table 6 - Results of Multiple Linear Regressions

\begin{tabular}{|c|c|c|c|c|c|c|c|}
\hline \multirow[t]{2}{*}{ Model } & \multicolumn{2}{|c|}{ Unstandardized Coefficients } & \multirow{2}{*}{$\begin{array}{c}\text { Standardized Coefficients } \\
\text { Beta }\end{array}$} & \multirow[t]{2}{*}{$t$} & \multirow[t]{2}{*}{ Sig. } & \multicolumn{2}{|c|}{ Collinearity Statistics } \\
\hline & B & Std. Error & & & & Tolerance & VIF \\
\hline (Constant) & 45,844 & 8,802 & & 5,208 & 0,000 & & \\
\hline $\mathrm{KI}$ & 1,048 & 0,189 & 0,471 & 5,551 & 0,000 & 0,730 & 1,371 \\
\hline $\mathrm{KE}$ & 0,266 & 0,100 & 0,235 & 2,663 & 0,009 & 0,676 & 1,480 \\
\hline KS & $-0,148$ & 0,115 & $-0,104$ & $-1,288$ & 0,200 & 0,812 & 1,231 \\
\hline $\mathrm{JP}_{1}$ & $-2,584$ & 3,289 & $-0,082$ & $-0,786$ & 0,434 & 0,487 & 2,053 \\
\hline $\mathrm{JP}_{2}$ & $-3,196$ & 3,534 & $-0,087$ & $-0,904$ & 0,368 & 0,562 & 1,779 \\
\hline $\mathrm{JP}_{3}$ & $-1,449$ & 3,729 & $-0,037$ & $-0,389$ & 0,698 & 0,579 & 1,727 \\
\hline $\mathrm{JP}_{4}$ & 1,418 & 3,562 & 0,039 & 0,398 & 0,691 & 0,553 & 1,807 \\
\hline
\end{tabular}


Table 6 shows the $F$ test testing the independent variables (KI, KE, KS, JP) that simultaneously have an influence on the dependent variable (SE). The value of significance $F=0,000<\alpha=0.05$. This means that the model used in this study is feasible (fit).

Multiple linear regression model is used to analyze the influence of each variable of intellectual intelligence, emotional intelligence, spiritual intelligence, and type of accounting profession on the ethical attitude of master accounting students with the help of SPSS program.

The results of multiple linear regression analysis are presented as follows:

$$
\mathrm{SE}=45,844+1,0481 \mathrm{KI}+0,266 \mathrm{KE}-0,148 \mathrm{KS}-2,5848 \mathrm{JP}_{1}-3,196 \mathrm{JP}_{2}-1,449 \mathrm{JP}_{3}+1,418 \mathrm{JP}_{4}
$$

The regression coefficient of $\mathrm{KI}$ variable is 1.048. Coefficient marked positive and significant means if the variable of intellectual intelligence increase one unit and other variable is considered constant then variable of ethical attitude of master accounting student increase.

KE variable regression coefficient is 0,266 . Coefficients marked positive and significant means if the emotional intelligence variable increases one unit and other variables are considered constant then the ethical attitude variable of master accounting students increases.

The regression coefficient of KS variable is -0.148 . Coefficient marked negative and insignificant meaning if the variable of spiritual intelligence increase one unit and other variable is considered constant hence variable of student's ethical attitude is not change.

The regression coefficient of variable $\mathrm{JP} 4_{1}$ equal to $-2,584$. Coefficient marked negative and insignificant meaning if variables of profession type of public accountant increase one unit and another variable is considered constant hence variable of the ethical attitude of accounting student does not change.

The regression coefficient of variable $\mathrm{JP}_{2}$ is -3.196 . Coefficient marked negative and insignificant meaning if variables type of management accountant profession increased one unit and other variables are considered constant then the variable ethical attitude of accounting students did not change.

The regression coefficient of variable $\mathrm{JP} 4_{3}$ equal to $-1,449$. Coefficient marked negative and insignificant meaning if a variant of profession type of educator accountant increases one unit and another variable is considered constant hence variable of the ethical attitude of accounting student does not change.

The regression coefficient of variables JP44 is 1.418. Coefficient marked positive and insignificant meaning if variables of government accountant profession type increase one unit and other variable is considered constant hence variable of the ethical attitude of accounting student do not change.

The test results of the influence of each independent variable $(X 1, X 2, X 3, X 4)$ on the dependent variable $(\mathrm{Y})$ are as follows:

1. The influence of intellectual intelligence on the accounting student's ethical attitude shows that the significance value $t=0,000<\alpha=0.05$ then the intellectual intelligence variable positively influences the ethical attitude of the accounting student, the first hypothesis $(\mathrm{H} 1)$ is acceptable;

2. The Influence of Emotional Intelligence on Ethical Attitudes of Accounting Students The results showed that the significant value $t=0.009<\alpha=0.05$ then the emotional intelligence variable positively influences the ethical attitude of accounting students, then the second hypothesis $(\mathrm{H} 2)$ is acceptable;

3. Effect of Spiritual Intelligence on Student Ethical Attitudes Accounting research results show that significant value $t=0.200>\alpha=0.05$, then the variable of spiritual intelligence does not positively affect the ethical attitude of accounting students, then the third hypothesis $(\mathrm{H} 3)$ can be rejected;

4. The Influence of Accountant Profession Type on Ethical Attitudes of Accounting Student: 
- the result of research indicate that significant value $t=0,434>\alpha=0,05$, hence variable of the type of Profession of Public Accountant does not have a positive effect on accountant ethical attitude of the ethical attitude of accounting students;

- The results showed that significant value $t=0.368>\alpha=0.05$, then variable Type Professional Accountant Management does not positively affect the ethical attitude of accounting students;

- The results showed that significant value $t=0.698>\alpha=0.05$, then variables Type Professional Accountant Educators have no positive effect on the ethical attitude of accounting students;

- The results showed that the significant value $t=0.691>\alpha=0.05$, then the variable Type of Professional Accountant Government has no positive effect on the ethical attitude of accounting students;

- The results showed that the significant value $t=0.492>\alpha=0.05$, then the variables Other Accountants Professional type does not positively affect the ethical attitude of accounting students.

The fourth hypothesis $(\mathrm{H} 4)$ can be rejected.

\section{DISCUSSION OF RESULTS}

Based on Theory planned behavior (TPB) that in conducting the behavior for every individual, it has a perception of beliefs that control it. The intellectual intelligence possessed by each individual can be the basis of control in behaving. The intellectual intelligence that also affects the cognitive component of the attitude forming process that is knowledge, will form certain beliefs and opinions about the object of attitude, including ethical attitudes.

The ability owned by the students that related to intellectual intelligence is able to give confidence to students in behaving in accordance with the attitude and subjective norm prevailing in the environment. In terms of student accounting environments, the intellectual intelligence of each student will provide the confidence drive to be ethical that is indeed needed in the world of accounting.

Based on the research that has been done, the intellectual intelligence of master accounting students is able to make students to understand problems, speak good, show curiosity in various problems, know how to achieve problem-solving which will shape the ethical attitude of master accounting students. So that master accounting students can develop intelligence capabilities that are based on the accountant's ethical code in living the profession as an accountant.

Theory of planning behavior (TPB) has a control of perceived behavior. Each individual has different behavior controls in accordance with his belief in what he considers to control. Emotional intelligence is also an affective component in the formation of attitudes that related to feelings of pleasure or displeasure and is closely related to the value system held by the attitude owner. It's relationship with the value system adopted by the attitude owner. Emotional intelligence is a benchmark for the individual's emotional control ability in influencing his attitude and behavior

Emotional intelligence is a benchmark for the individual's emotional control ability in influencing his attitude and behavior. This means that emotional intelligence affects the ethical attitude of master accounting students because it improves self-control ability, stimulates perseverance, and can self-motivate the students themselves.

Based on the research that has been done then the emotional intelligence of master accounting students can improve the ability to recognize feelings, reach and evoke feelings to help the mind, understand feelings and meaning, and control feelings deeply so that helps the development of emotions, and thus will form an ethical attitude on accounting student. So that master accounting students can develop emotional control on the ethical attitude which is based on accountant ethics code in a profession as an accountant.

Based on Theory planned behavior (TPB) that in doing a behavior every individual has a perception of beliefs that control it. Sufficient spiritual intelligence is a contributing factor in the control of individual behaviors in accordance with objective attitudes and norms 
prevailing in the environment. Good spiritual intelligence control in the students will affect the student's ethical attitude, because with the calm and confidence in facing problems in learning will lead the students to remain ethical in solving them.

Based on the research that has been done spiritual intelligence has no effect on the ethical attitude can be seen from the respondent's lowest-valued response on spiritual intelligence variables, that is "when in a debate, l'd rather succumb though my opinion is better" which refers to the aspect of holistic view. This aspect indicates that master accounting student are less able to see the problem by only looking from one side, and less considering other sides. While the responses of respondents on ethical attitude variables, showed respondents have a fairly high response in using moral judgment and professional judgment. So, it can be concluded that the high or low self-holistic thinking in facing a problem, does not affect the holistic view in the world of work in other words this research shows the high or low spiritual intelligence does not affect the ethical attitude of master accounting students who work as accountants.

Professional ethics is a characteristic of a profession that distinguishes a profession from another profession, which serves to regulate the behavior of its members (Murtanto and Marini, 2003). In theory ethical profession (code of ethics) owned by the accounting profession, there are rules that become the foundation for the existence of the accounting profession. The code of ethics is designed to serve as a rule of ethical conduct for members of the profession aimed at maintaining the reputation and trust of the community so that the profession can still exist and survive. So that master accounting students who have a profession as an accountant has a good ethical attitude, because it is accustomed to carry out the work in accordance with the ethical standards of accountants is the code of ethics of accountants.

Based on the research that has been done, the types of accounting professions consisting of public accountants, management accountants, accountant educators, and government accountants have no effect on the ethical attitude of master accounting students. Experience in the world of work that refers to the ethical code of accounting profession and business ethics courses and professions that have been taken by master accounting student in the process of studying at the level of bachelor degree and master degree does not encourage the influence of ethical attitudes in the background of students who work as accountants. The number of factors outside the type of accounting profession that influences the individual student life like work environment, and work culture in each workplace, so that any type of accounting profession does not affect the ethical attitude of the students.

\section{CONCLUSION}

Based on the results of the analysis and discussion of research results, it can be concluded that intellectual intelligence and emotional intelligence affect the ethical attitude of master accounting students, while spiritual intelligence and different types of accounting professions have no effect on the ethical attitude of master accounting students.

Based on the conclusions, it can be given advice for master accounting students to be given courses ethics in the realm of accounting education that emphasizes the graduation of intellectual ability, emotional ability without ignoring the spiritual ability and emphasis code of accountant ethics can also be reasserted in the learning process of master accounting students, to be used simultaneously and conscious as a professional accountant.

Adding other variables such as social intelligence, organizational experience, and environmental circumstances may also affect an individual's ethical attitude. In addition, there are other variables that are expected to influence ethical attitudes, such as age, education level, gender, the locus of control, and equity sensitivity.

\section{REFERENCES}

1. Ayman, Sawaf, \& Cooper Robert, P. (1998). Executive EQ. Jakarta: PT Gramedia Pustaka Utama. 
2. Azwar. (2005). Sikap Manusia : Teori dan Pengukurannya. Yogyakarta: Pustaka Pelajar.

3. Chakraborty, S. K. \& Chakraborty, D. (2004). The transformed leader and spiritual psychology: a few insights. Journal of Organizational Change Management, 17(2),194210. https://doi.org/10.1108/09534810410530610

4. Dewanto, A. M., \& Nurhayati, S. (2009). Kecerdasan Spiritual Terhadap Sikap Etis dan Prestasi Mahasiswa Akuntansi (Studi Pada Perguruan Tinggi di Kota Pekalongan), (1).

5. Fitri, Utami \& Indriawati, W. (2006). Muatan Etika Dalam Pengajaran Akuntansi Keuangan dan Dampaknya Terhadap Persepsi Etika Mahasiswa: Studi Eksperimen Semu. Simposium Nasional Akuntansi IX.

6. Goleman, D. (2000). Working With Emotional Intelligence. Jakarta: PT Gramedia Pustaka Utama.

7. Goleman, D. (2009). Emotional Intelligence. Kecerdasan Emosional Mengapa El Lebih Penting daripada IQ. Jakarta: PT Gramedia Pustaka Utama.

8. Ika, D. (2011). Pengaruh Kecerdasan Emosional dan Spiritual Terhadap Sikap Etis Mahasiswa Akuntansi Dipandang dari Segi Gender (Studi pada Perguruan Tinggi Negeri di Kota Medan). Nal Keuangan \& Bisnis Jurnal Keuangan \& Bisnis, Volume 3.

9. Jamaluddin dan, \& Indriasari, R. (2011). Pengaruh Kecerdasan Intelektual, Kecerdasan Emosional , dan Kecerdasan Spiritual terhadap Etika Mahasiswa Akuntansi Fakultas Ekonomi Universitas Tadulako. Pamator, 4(1), 46-56.

10. Jogiyanto. (2007). Sistem Informasi Keperilakuan. Yogyakarta: Andi Offset.

11. Lucyanda, J., Akuntansi, P. S., Endro, G., \& Manajemen, P. S. (2013). Faktor-faktor yang memengaruhi perilaku etis mahasiswa akuntansi universitas bakrie. Jurnal Ekonomi Dan IImu Sosial, 2, 1-34.

12. Pasiak, T. (2002). Revolusi IQ/EQ/SQ; Menyingkap Rahasia Kecerdasan Berdasarkan al-Qur'an dan Neurosains Mutakhir. Bandung: Mizan.

13. Purwanto, N. (2003). Psikologi Pendidikan. Bandung: PT Remaja Rosdakarya.

14. Robins, Stephen P. dan Judge, T. A. (2008). Organizational Behavior (13th ed.). US: Prentice Hall.

15. Secord, P. F., \& Backman, C. W. (1964). Social Psychology. New York: McGraw - Hill.

16. Shahhosseini, M., Daud Silong, A., \& nak Uli, J. (2012). The Role of Emotional Intelligence on Job Performance. International Journal of Business and Social Science, 3(21), 241-246. https://doi.org/10.3923/sscience.2012.125.129

17. Sugiarto, D. S. (2000). Metode Statistika Untuk Bisnis Dan Ekonomi. Jakarta: PT Gramedia Pustaka Utama.

18. Trihandini, R. a F. M. (2005). Analisis Pengaruh Kecerdasan Intelektual , Kecerdasan Emosi dan Kecerdasan Spiritual terhadap Kinerja Karyawan Program Studi Magister Manajemen Program Pascasarjana Universitas Diponegoro Semarang. Unpiblished Phd Theses, 1-94.

19. Ward, S. P., Ward, D. R., \& Deck, A. B. (1993). Certified public accountants: Ethical perception skills and attitudes on ethics education. Journal of Business Ethics, 12(8), 601-610. https://doi.org/10.1007/BF01845897

20. Wardana, A., \& Mimba, N. (2016). Pengaruh Kecerdasan Intelektual, Kecerdasan Emosional, Kecerdasan Spiritual, Dan Gender Pada Sikap Etis Mahasiswa Magister. EJurnal Ekonomi Dan Bisnis, 10, 3501-3530. Retrieved from http://ojs.unud.ac.id/index.php/EEB/article/view/22581

21. Zakiah, F. (2013). Pengaruh Kecerdasan Intelektual, Kecerdasan Emosional Dan Kecerdasan Spiritual Terhadap Pemahaman Akuntansi (Studi Empiris Mahasiswa Jurusan Akuntansi Angkatan Tahun 2009 di Universitas Jember). Universitas Jember.

22. Zohar, D. dan Marshall, I. (2005). SQ Kecerdasan Spriritual. Bandung: Mizan. 